\title{
Polyphasic growth in fish: a case study with Corydoras paleatus (Siluriformes, Callichthyidae)
}

\author{
José R. S. Barradas ${ }^{1}$, Isabel S. Lermen², Gabriel G. Larré' \\ Thaís P. Martins ${ }^{3} \&$ Nelson F. Fontoura ${ }^{1}$
}

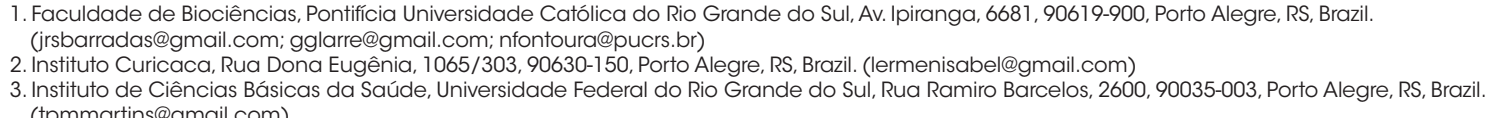

(†pmmartins@gmail.com)

Received 12 May 2016

Accepted 14 June 2016

DOI: 10.1590/1678-4766e2016017

\begin{abstract}
A weight-length relationship was established for Corydoras paleatus (Jenyns, 1842) (Siluriformes, Callichthyidae) ( $\mathrm{n}=596$ ) from samples taken in November-December 2009 and March-April 2010, in Pinguela Lagoon (2946'57'S; 50¹1'16”W), Rio Grande do Sul, Brazil. The species showed a polyphasic allometric growth pattern, each stanza described by an independent power equation controlled by a switch function: $\mathrm{W}=\mathrm{a}_{1} \mathrm{~L}^{\mathrm{b}}{ }_{1}$. $\left(1+e^{\mathrm{Rsc}} \text { ( (L-SCP) }\right)^{-1}+\mathrm{a}_{2} \mathrm{~L}^{\mathrm{b}_{2}} \cdot\left[1-\left(1+\mathrm{e}^{\mathrm{Rsc}} \text {. (L-SCP)}\right)^{-1}\right]$; where $\mathrm{W}$ is the expected weight for a specific length $\mathrm{L}, \mathrm{a}_{1}$ and $\mathrm{a}_{2}$ are the proportionality coefficients for stanzas 1 and 2, $b_{1}$ and $b_{2}$ are the allometric coefficients for stanzas 1 and 2, $R_{\mathrm{sc}}$ is the stanza changing rate for the switch function and SCP is the stanza changing point for the switch function. The stanza changing point was estimated as $5.28 \mathrm{~cm}$, corresponding with the length at first maturity for this species $\mathrm{L}_{\text {mat }}(5.29 \mathrm{~cm})$. Our data suggest that a complex growth pattern can be in nature, and perhaps not often identified because trends are obscured by natural variability.
\end{abstract}

KEYWORDS. Allometric growth, length at first maturity, reproduction, sexual maturity, length-weight relationship.

RESUMO. Crescimento polifásico em peixes: estudo de caso com Corydoras paleatus (Siluriformes, Callichthyidae). Foi estabelecida uma relação peso-comprimento para Corydoras paleatus (Jenyns, 1842) (Siluriformes, Callichthyidae) $(\mathrm{n}=596)$ a partir de amostras obtidas em novembro-dezembro de 2009 e março-abril de 2010, na lagoa da Pinguela (2946'57'S; 50¹1’16”'W), Rio Grande do Sul, Brasil. A espécie apresentou um padrão de crescimento alométrico polifásico, cada estágio descrito por uma equação de potência independente e controladas por uma função de interruptora: $\mathrm{W}=\mathrm{a}_{1} \mathrm{~L}^{\mathrm{b}}{ }_{1} \cdot(1+$ $\left.\mathrm{e}^{\mathrm{Rsc}} \cdot(\mathrm{L}-\mathrm{SCP})\right)^{-1}+\mathrm{a}_{2} \mathrm{~L}^{\mathrm{b}}{ }_{2} \cdot\left[1-\left(1+\mathrm{e}^{\mathrm{Rsc}} \text {. (L-SCP) }\right)^{-1}\right]$; onde $\mathrm{W}$ é o peso esperado para um comprimento $\mathrm{L}, \mathrm{a}_{1}$ e $\mathrm{a}_{2}$ são os coeficientes de proporcionalidade para

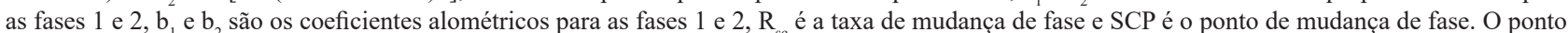
de mudança fase foi estimado em $5,28 \mathrm{~cm}$, correspondendo com o comprimento de primeira maturação desta espécie $\left(\mathrm{L}_{\text {mat }}\right)(5,29 \mathrm{~cm})$. Nossos dados sugerem que um padrão de crescimento complexo pode ser frequente na natureza, e que talvez muitas vezes não seja identificado porque as tendências são obscurecidas pela variabilidade natural.

PALAVRAS-CHAVE. Crescimento alométrico, tamanho de primeira maturação, reprodução, maturação sexual, relação peso-comprimento.

The weight-length relationship (WLR) is considered frequently as "second class" science (FrOESE, 2006), and just regular task for any fishery biologist. Research about WLR are frequently published only as short-communication for species that this information is not yet known (FroEsE, 2006). As a result, specific work on weight and length do not stand out, restricting knowledge of the WLR to a very small number of species (KULBICKI et al., 2005).

Of course, it's easy to understand the need of WLR for commercial fishery, when we need to convert both measurements as an ordinary task. However, the parameters of the WLR, as the proportionality coefficient (a) and the allometric coefficient (b) could inform several aspects of the fish biology, as the general growth pattern or seasonal changes in the fish condition (FrOESE, 2006). The amount of information that could be inferred using this general approach makes it very useful the understand ecological patterns, even for small and not commercial fish species.

FROESE et al. (2014) made a recent revision on this subject, including data from 1821 species with available information. These authors found a general pattern concerning fish WLR: (1) as a general average, fish present positive allometric growth factor $(b>3)$; (2) the allometric factor depends on the fish body shape, ranging from 3.12 for elongated fish to 3.01 for short and deep fish.

Although, as identified by Bervian et al. (2006) and FonTOURA et al. (2010), the growth pattern of fish could be too complex to be described by a simple power function, as food source and quality is not constant in nature, and adaptation to several aspects of the fish life cycle, as habitat shift, migration, ontogenetic shift of feeding habitats and reproductive strategies can change the energetic budget, 
altering the general pattern of growth. In this regard, BERVIAN et al. (2006) revised the relative growth function and proposed a polyphasic model, where the growth pattern can be divided into different stanzas, each stanza described by a regular power function, but connected all together by switch (logistic) equations turning on or off a growth segment in relation to a specific life cycle period.

The polyphasic growth model was already applied to describe the WLR for Astyanax jacuhiensis Cope, 1984, and Cheirodon ibicuhiensis Eigenmann, 1915 (FonTOURA et al., 2010). In this study, a change in the growth pattern of these species was described with two different stanzas, each stanza following an independent power equation controlled by a switch function, as proposed by BERVIAN et al. (2006). For $C$. ibicuhiensis, a change in the growth pattern was related to the attainment of sexual maturity. On the other hand, for $A$. jacuhiensis there was no perfect match among the stanza changing length and the available information concerning the size at first maturity. FONTOURA et al. (2010) also identified that even the two-stanza growth model did not perfectly describe the full data series for A.jacuhiensis, with identified anomalies for animals above $8 \mathrm{~cm}$. Nevertheless, a more-complex model was not applied because few large animals were available.

Corydoras paleatus Jenyns, 1842, (Siluriformes, Callichthyidae) is found in the Paraná River basin and southern coastal rivers of Brazil and Uruguay (GARAVELLO et al., 1997). These fish form large schools in sandy shoals, where they feed on invertebrates and organic material (MEGA \& BEMVENUTI, 2006). Reproduction occurs year-round, but with increased intensity in February (BERVIAN \& FonTOURA, 1994).

As identified by previous work, polyphasic growth could be more frequent in nature than expected, and maybe unknown for most species due to standard methodology usually applied to fit WLR. In the present study, we aimed to estimate the length at first maturity $\left(\mathrm{L}_{50}\right)$ according to the Gonadossomatic Index (GSI) using a mathematical approach (MARQues et al., 2007; FonTOURA et al., 2009) and identify if a polyphasic growth pattern is present for C. paleatus, verifying a possible relationship between the stanza changing length and aspects of the fish biology, as the attainment of sexual maturity.

\section{MATERIAL AND METHODS}

Samples of $C$. paleatus were taken in November December 2009 and March - April 2010, by means of a beach seine net ( $50 \mathrm{~m}$ long, $3 \mathrm{~m}$ high, and $5 \mathrm{~mm}$ mesh size) in the Pinguela Lagoon (20 46' 57'S; 50¹1'16'W; southern Brazil). The hauls were made on a sandy beach and around macrophyte beds.

Altogether, 674 individuals were captured and 596 were utilized for data analysis after outlier removal. Animals were anaesthetized in eugenol $\left(285 \mathrm{mg} \cdot \mathrm{l}^{-1}\right)$ for $10 \mathrm{~min}$, field-cooled with ice and frozen in the laboratory $\left(-18^{\circ} \mathrm{C}\right)$. Biometric measurements for each sexed indi- vidual were taken: total length $\left(\mathrm{L}_{\mathrm{t}}\right.$, to nearest $\left.0.1 \mathrm{~mm}\right)$; total weight $\left(\mathrm{W}_{\mathrm{t}}\right.$; to nearest $\left.0.01 \mathrm{~g}\right)$, and female gonadal weight $(\mathrm{n}=120$; $\mathrm{W}_{\mathrm{g}}$; to nearest $0.01 \mathrm{~g}$ ). Specimens from the same locality were deposited in the collection of the Museu de Ciências e Tecnologia - PUCRS (MCT, catalog number 9549).

For length-weight analysis, we assumed as outlier cutpoint the distance from the expected weight of \pm 1.96 residual standard deviation. To avoid error caused by imprecision of weight measures for small individuals and by the low number of big individuals that could introduce artificial breaks in the growth pattern, $2.5 \%$ of data was removed from each edge of the cloud of points.

Aiming to identify possible relation between a polyphasic growth and the attainment of sexual maturity, as described by the literature (BERVIAN et al., 2006; FONTOURA et al., 2010), the Gonadossomatic Index (GSI) (Equation 1, below) and length at first maturity $\left(\mathrm{L}_{\text {mat }}\right)$ (Equation 2, below) were estimated for 120 female individuals, as suggested by MARQUes et al. (2007). To apply the methodology proposed by MARQUES et al. (2007) to our data set, one basic modification had to be made: instead of GSI average we have used GSI median to identify $\mathrm{L}_{\text {mat }}$. Using the median it's possible to avoid the problem caused by non-normality of data. Individual GSI is estimated as follow (Equation 1): $\mathrm{GSI}=\left(\mathrm{W}_{\mathrm{g}} \cdot \mathrm{W}_{\mathrm{t}}\right) \cdot 100$; where $\mathrm{W}_{\mathrm{g}}$ is the gonadal weight and $\mathrm{W}_{\mathrm{t}}$ is the total weight. Size at first maturity $\left(\mathrm{L}_{\text {mat }}\right)$ can then be estimated by solving the following equation (2): $\mathrm{GSI}_{\mathrm{med}}=$ $\mathrm{GSI}_{\text {min }}+\left(\mathrm{GSI}_{\text {max }}-\mathrm{GSI}_{\text {min }}\right) \cdot\left(1+\mathrm{e}^{-\mathrm{R}_{\mathrm{GSI}} \cdot(\mathrm{L} \text {-Lmat) }}\right)^{-1}$; where GSI ${ }_{\text {med }}$ is the GSI median for females in each length class, GSI ${ }_{\text {min }}$ is the GSI median for juvenile females, GSI ${ }_{\max }$ is the GSI median for adult females, $\mathrm{R}_{\mathrm{GSI}}$ is the transition rate from juvenile to adult stage, $\mathrm{L}$ is the average total length for each length class and $\mathrm{L}_{\text {mat }}$ is the length at first maturity.

To apply the polyphasic growth model proposed by BERVIAN et al. (2006), the first procedure was to adjust a regular WLR (3): $\mathrm{W}=\mathrm{aL}^{\mathrm{b}}$; where $\mathrm{W}$ is the expected weight (g) for a specific total length $(\mathrm{L}, \mathrm{cm})$, a is the proportionality coefficient and Bis the allometric coefficient.

Aiming to identify any possible trend resulting from the regular WLR, proportional residuals (PR) were plotted as a function of the observed total length, according to the follow equation (4): $\mathrm{PR}=\left(\mathrm{W}_{\mathrm{o}}-\mathrm{W}_{\mathrm{p}}\right) \cdot \mathrm{W}_{\mathrm{p}}^{-1}$; where $\mathrm{PR}$ is the proportional residuals, $\mathrm{W}_{\mathrm{o}}$ is the observed weight and $\mathrm{W}_{\mathrm{p}}$ is the predicted weight. If the species do not present a polyphasic growth pattern and the regular WLR is well fitted, the residual pattern should be displayed as an unbiased data cluster centered on the y-axis zero baseline. But if there is any identifiable shift in the residual pattern, a break point could be a sign of change in the species growth cycle (BERVIAN et al., 2006). Proportional residuals were applied instead of regular residuals to correct bias from heteroscedasticity.

According to BERVIAN et al. (2006), the WLR could be described as follows (5): $\mathrm{W}=\mathrm{a}_{1} \mathrm{~L}^{\mathrm{b}} \cdot \mathrm{F}_{\mathrm{s}}+\mathrm{a}_{2} \mathrm{~L}_{2}{ }_{2} \cdot\left(1-\mathrm{F}_{\mathrm{s}}\right)$; where $\mathrm{W}$ is the expected weight for a specific length $\mathrm{L}, \mathrm{a}_{1}$ and $\mathrm{a}_{2}$ are the proportionality coefficients for the first and second stanzas, $b_{1}$ and $b_{2}$ are the allometric coefficients for the first and second stanzas and $\mathrm{F}_{\mathrm{s}}$ is the Switch Function 
(6): $F_{s}=\left(1+e^{\text {Rsc }} \text {. (L-SCP) }\right)^{-1}$; where $F_{s}$ is the Switch Function (ranging from 0 to 1 ), $\mathrm{R}_{\mathrm{sc}}$ is the stanza changing rate, $\mathrm{L}$ is the total length and SCP is the stanza changing point.

Once the uniphasic and polyphasic models were adjusted, the SCP was utilized as a breakpoint for two linear regressions applied to the proportional residuals according to total length, aiming to identify any pattern in each segment of the cloud of points.

The Coefficient of Determination, $\mathrm{R}^{2}$, was calculated for regular (Huxley) and polyphasic models accordind to ZAR (1999) (7): $\mathrm{R}^{2}=1$ - RSS/TSS; where RSS is the Residual Sum of Squares and TSS is the Total Sum of Squares. To avoid deformation derived from data log-transforming (SмIтH, 1980), all nonlinear equations were adjusted using the $n l s L M$ function for nonlinear models adjustment from minpack. Im (ElZHOv et al., 2013) package for $R$ environment ( $\mathrm{R}$ Core TeAm, 2015). The linear regressions were adjusted using the $l m$ routine from stats package, also designed for $R$ environment (R CORE TEAM, 2015).

\section{RESULTS}

The 596 specimens of $C$. paleatus included in lengthweight analysis had total lengths ranging from 3.6 to 6.74 $\mathrm{cm}$, and weights ranging from 0.77 to $5.97 \mathrm{~g}$. The length frequency distribution showed bi-modality for all individuals (Fig. 1). The GSI distribution according to fish length shows that $C$. paleatus reaches the sexual maturity at approximately $5.29 \mathrm{~cm}$ (Fig. 2; Tab. I).

The proportional residuals obtained by adjusting the traditional Huxley model showed a pattern which divides the length information in two datasets. As seen by the linear regression lines (Fig. 3, gray lines; Tab. I), the first dataset, ranging from 3.6 to approximately $5.6 \mathrm{~cm}$ in total length, and the second data cluster, ranging from approximately 5.6 to $6.74 \mathrm{~cm}$, has a clear and significant decreasing trend ( $\mathrm{p}$ $<0.001$ for both; Tab. I). Fig. 3 shows the LWR obtained

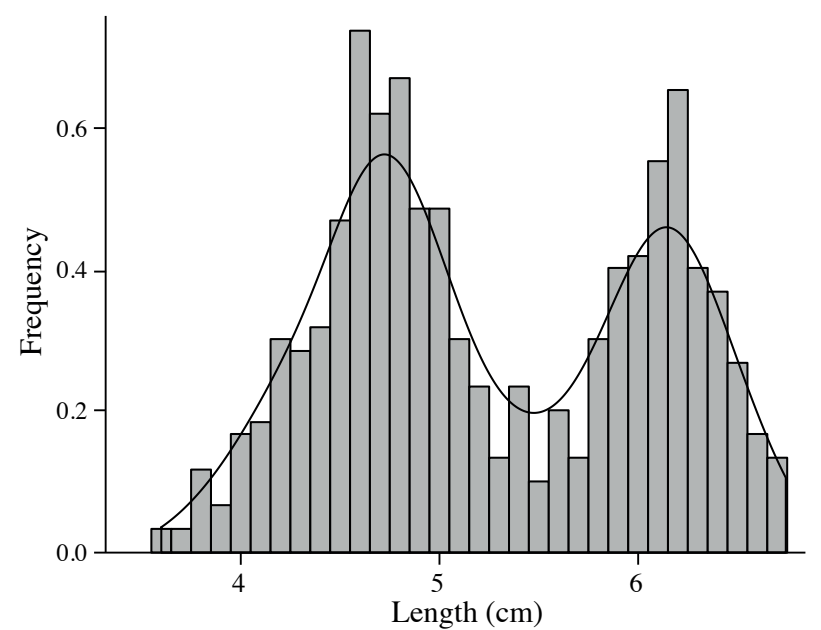

Fig. 1. Length frequency distribution of Corydoras paleatus (Jenyns, 1842) - samples taken in November-December 2009 and March-April 2010, in Pinguela Lagoon, Rio Grande do Sul, Brazil. with the Huxley model.

Assuming two growth phases for the polyphasic model and setting the start SCP value in the adjustment routine as $5.3 \mathrm{~cm}$, the approximated length where a change in the growth pattern occurs according to the proportional residuals plotting, we could identify one clear breakpoint very close to $\mathrm{L}_{\text {mat }}\left(\mathrm{SCP}=5.58 \mathrm{~cm} ; \mathrm{L}_{\text {mat }}=5.29 \mathrm{~cm}\right)$, as seen on figure 4 and 5 . Once the data set was divided into two stanzas, each growth phase could be described by a regular power function, with proportional residuals well distributed around the y-zero baseline. Both first and second linear regressions showed no significant trend with the polyphasic model, with $\mathrm{p}$ reaching 0.617 and 0.785 for the first and second regression, respectively (Tab. I).

Using the uniphasic model (Huxley) the allometric coefficient (b) was adjusted as higher than $3(b=3.259$; positive allometrv: Tab. I). but applving the polvphasic model

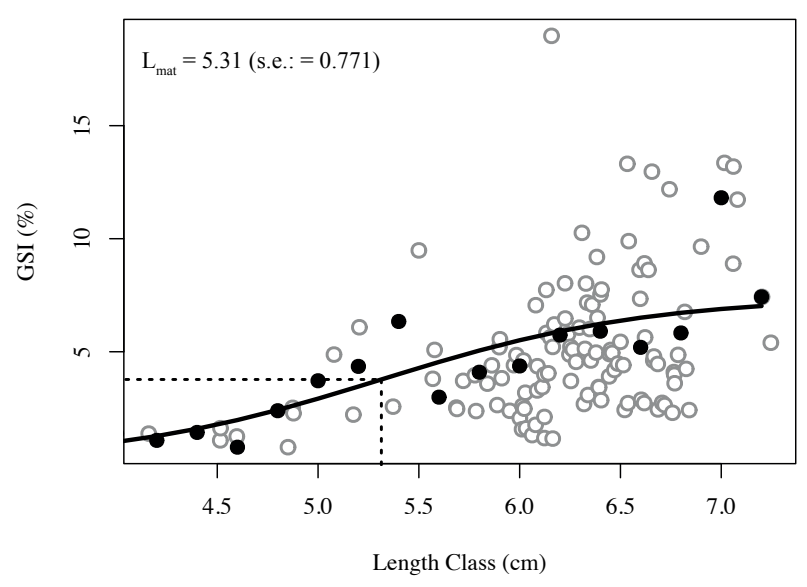

Fig. 2. Gondossomatic Index (GSI) according to fish total length for Corydoras paleatus (Jenyns, 1842) - samples taken in November-December 2009 and March-April 2010, in Pinguela Lagoon, Rio Grande do Sul, Brazil $(n=120)$. Gray dots: GSI individual measures; black dots: GSI median; solid black line: logistic regression for $\mathrm{L}_{\text {mat }}$ calculation; dotted line: estimated $\mathrm{L}_{\text {mat }}$ according to GSI (MARQUES et al., 2007).

Tab. I. Regression coefficients for Corydoras paleatus (Jenyns, 1842) - samples taken in November-December 2009 and March-April 2010, in Pinguela Lagoon, Rio Grande do Sul, Brazil - obtained by Uniphasic (Huxley) and Polyphasic models - mean $( \pm$ S.E.).

\begin{tabular}{|c|c|c|c|c|c|}
\hline & & \multicolumn{2}{|c|}{ Uniphasic } & \multicolumn{2}{|c|}{ Polyphasic } \\
\hline \multirow{4}{*}{ 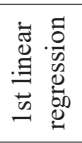 } & intercept & 0.305 & $(0.071)$ & $-0,020$ & $(0.040)$ \\
\hline & slope & -0.068 & $(0.016)$ & -0.004 & $(0.008)$ \\
\hline & $\mathrm{p}$-value & \multicolumn{2}{|c|}{$<0.001$} & \multicolumn{2}{|c|}{0.617} \\
\hline & $\mathrm{R}^{2}$ & \multicolumn{2}{|c|}{0.081} & \multicolumn{2}{|c|}{$<0.001$} \\
\hline \multirow{4}{*}{ 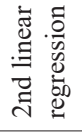 } & intercept & 0.496 & $(0.139)$ & 0.028 & $(0.103)$ \\
\hline & slope & -0.079 & $(0.022)$ & -0.005 & $(0.017)$ \\
\hline & p-value & \multicolumn{2}{|c|}{$<0.001$} & \multicolumn{2}{|c|}{0.785} \\
\hline & $\mathrm{R}^{2}$ & \multicolumn{2}{|c|}{0.059} & \multicolumn{2}{|c|}{$<0.001$} \\
\hline \multirow{8}{*}{ 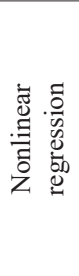 } & $a_{1}$ & 0.011 & $(0.001)$ & 0.017 & $(0.004)$ \\
\hline & $\mathrm{b}_{1}$ & 3.259 & $(0.033)$ & 2.969 & $(0.166)$ \\
\hline & $\mathrm{a}_{2}$ & & - & 0.025 & $(0.005)$ \\
\hline & $\mathrm{b}_{2}$ & & - & 2.806 & $(0.101)$ \\
\hline & $\mathrm{R}_{\mathrm{SC}}$ & & - & 10.8 & $(6.112)$ \\
\hline & SCP & & - & 5.58 & $(0.071)$ \\
\hline & $\sum \mathrm{PR}^{2}$ & \multicolumn{2}{|c|}{0.411} & \multicolumn{2}{|c|}{0.389} \\
\hline & $\mathrm{R}^{2}$ & \multicolumn{2}{|c|}{0.999} & \multicolumn{2}{|c|}{0.999} \\
\hline
\end{tabular}



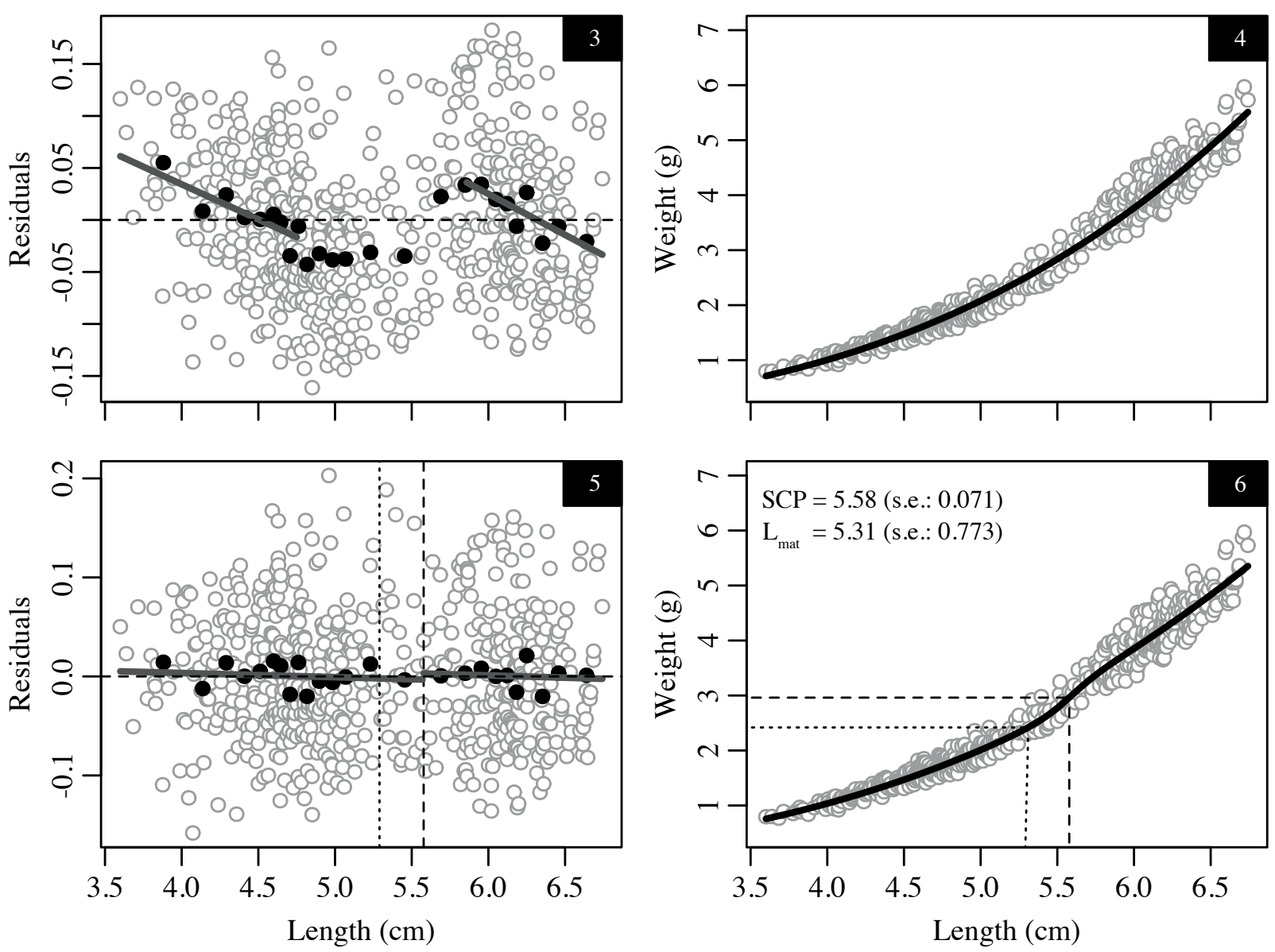

Figs 3-6. Weight-length relationship of Corydoras paleatus (Jenyns, 1842) - samples taken in November-December 2009 and March-April 2010, in Pinguela Lagoon, Rio Grande do Sul, Brazil. Figs 3 and 5: proportional residuals according to fish total length obtained by Uniphasic (Huxley) and Polyphasic models respectively (gray dots: individual measures; black dots: moving average of 30 individuals measures; gray lines: linear regressions for each data cluster). Linear regressions were fitted using different data series, first and last thirds in 2 and first and second phases according to polyphasic model in 4. Figs 4 and 6: total weight according to total length obtained by Uniphasic (Huxley) and Polyphasic models respectively (gray dots; individual measures; solid lines: estimated weight). Gray solid lines are SCP and black dotted lines are $\mathrm{L}_{\text {mat }}$, estimated according to GSI (MARQUES et al., 2007).

the allometric coefficient remained lower than 3 (negative allometry) for the entire life cycle of the species (Tab. I). The first phase, however, was very close to isometry $(b=2.969$; Tab. I). The polyphasic model showed a decreasing weight gain for animals larger than $5.58 \mathrm{~cm}$, with $\mathrm{b}$ reaching 2.806 .

By observing the residual distribution as a function of total length (Fig. 5), a random pattern around the zero baseline could be observed in polyphasic adjustment. No significance was identified in first and second linear regressions when using the polyphasic model (Tab. I), indicating a perfect adjustment to the dataset. Although growth trends were clearly identified (Fig. 3), in a global way, the Huxley model well describes the LWR for this species (Fig. 4), with $\Sigma$ PR slightly better for the polyphasic model, but reaching almost the same values for both models (Tab. I). The coefficient of determination $\left(\mathrm{R}^{2}\right)$ was equal for both models, reaching 0.99 .

\section{DISCUSSION}

Corydoras paleatus showed a clear polyphasic growth pattern, as described by BERVIAN et al. (2006) and Fontoura et al. (2010). Few studies have examined the reproductive biology and size at first maturity $\left(\mathrm{L}_{\text {mat }}\right)$ for $C$. paleatus. Modelling GSI according to MARQUES et al. (2007), the length at first maturity was estimated as $5.31 \mathrm{~cm}$ very close to $5.58 \mathrm{~cm}$, the estimated SCP, supporting the SCP as a breakpoint in fish growth caused by the reaching of sexual maturity, as suggested by BERviAn et al. (2006) for Micropogonias furnieri (Desmarest, 1823) and FonTourA et al. (2010) for C. ibicuhiensis.

A close relationship between size at first maturity $\left(\mathrm{L}_{\text {mat }}\right)$ and the SCP was proposed by BERVIAN et al. (2006) as a change in the energy budget from prioritizing growth to starting reproduction. Although the SCP value could be circumstantially associated with the attainment of reproduction in C. paleatus, other biological factors may be related to changes in the growth pattern for other species. An ontogenetic diet shift, changes in the pattern of habitat occupation, seasonal climate changes, and migrations are all factors that should be taken into account. 
In this regard, due to the possibility of use of an indeterminate number of phases, the polyphasic model can be an important tool for understanding the biology of fishes. It's possible to identify not only the length at first maturity, but also other great changes in growth caused by environmental conditions. For C. paleatus, however, only one major change in the growth pattern could be identified. As seen on Fig. 5, the random distribution of proportional residuals centered in y-zero baseline shows that only one breakpoint, dividing the model into two phases, is enough to describe the LWR. Our data indicates that, although several environmental factor could cause changes in the growth pattern, for $C$. paleatus only the attainment of sexual maturity appear to identifiable by the polyphasic model.

An important question in any attempt to model nature by using complex equations is the number of factors that should be applied. Extensive research has been carried out on this subject, as reviewed by BURNHAM \& ANDERSON (2002). As a general rule, any additional parameter could improve the predictive behavior of the model, but at the cost of increased complexity and loss of degrees of freedom. Model selection is usually related to a balance between the costs and benefits of using a certain number of parameters, as measured by the Akaike Information Criterion (AIC) (BURNHAM \& ANDERSON, 2002; JOHNSON \& OMLAND, 2004).

Despite the increased complexity, the key factor directing the option for applying the polyphasic model should not be strictly statistical, such as by seeking the best AIC values, but should be the possibility of identifying a change in the growth pattern that could reveal previously neglected biological events. In this respect, the polyphasic growth model should not be viewed merely as a way to describe the WLR, because the practical gain in terms of fitting quality could be minimal. The key factor is to view the method as a tool to explore the growth pattern as a flag signalling any change in the biological cycle of a species. In this sense, the application of a more-complex function, such as the polyphasic growth model, could indicate previously unknown anomalies and inspire new insights, guiding the design of research programs to understand fish biology in detail.

Acknowledgements. Financial support was provided by scholarships and research funds from $\mathrm{CNPq}$ to N. F. Fontoura.

\section{REFERENCES}

Bervian, G. \& Fontoura, N. F. 1994. Dinâmica populacional de Corydoras paleatus na lagoa Fortaleza, Rio Grande do Sul. III. Corydoras paleatus (Jenyns, 1842) (Teleostei, Callichtyidae). Biociências 2(2):15-23.

Bervian, G.; Fontoura, N. F. \& Haimovici, M. 2006. Statistical model of variable allometric growth: otolith growth in Micropogonias furnieri (Actinopterygii, Sciaenidae). Journal of Fish Biology 1:196-208.

BurNhAM, K. P. \& ANDERSON, D. R. 2002.Model selection and multimodel inference: a practical information-theoretic approach. New York, Springer Science \& Business Media. 488p.

Elzhov, T. V.; Mullen, K. M.; SPIESS, A-N. \& BolKer, B. 2013. minpack. Im: $\mathbf{R}$ interface to the Levenberg-Marquardt nonlinear leastsquares algorithm found in MINPACK, plus support for bounds. Avaliable at: $<$ http://www2.uaem.mx/r-mirror/web/packages/minpack. 1m/minpack.lm.pdf $>$. Accessed on: 25 May 2016.

Fontoura, N. F.; Braun, A. S. \& Milani, P. C. C. 2009. Estimating size at first maturity $\left(\mathrm{L}_{50}\right)$ from Gonadossomatic Index (GSI) data. Neotropical Ichthyology 7(2):217-222.

Fontoura, N. F.; Jesus, A. S.; Larre, G. G. \& Porto, J. 2010. Can weight/ length relationship predict size at first maturity? A case study with two species of Characidae. Neotropical Ichthyology 8(4):835-840.

FroESE, R. 2006. Cube law, condition factor and weight-length relationships: history, meta-analysis and recommendations. Journal of Applied Ichthyology 22:241-253.

Froese, R.; Thorson, J. T. \& Reyes, R. B. 2014. A Bayesian approach for estimating length-weight relationships in fishes. Journal of Applied Ichthyology 30(1):78-85.

Garavello, J. C.; Pavanelli, C. S. \& Suzuki, H. I. 1997. Caracterização da ictiofauna do rio Iguaçu. In: Agostinho, A. A. \& Gomes, L. C. Reservatório de Segredo: bases ecológicas para o manejo. Maringá, EDUEM. p. 61-84.

Johnson, J. B. \& OmLand, K. S. 2004. Model selection in ecology and evolution. Trends in Ecology \& Evolution 19(2):101-108.

Kulbicki, M.; Guillemot, N. \& Amand, M. 2005. A general approach to length-weight relationships for New Caledonian lagoon fishes. Cybium 29(3):235-252.

Marques, C. S.; Braun, A. S. \& Fontoura, N. F. 2007. Estimativa de tamanho de primeira maturação a partir de dados de IGS: Oligosarcus jenynsii, Oligosarcus robustus, Hoplias malabaricus, Cyphocharax voga, Astyanax fasciatus (Characiformes), Parapimelodus nigribarbis, Pimelodus maculatus, Trachelyopterus lucenai, Hoplosternum littorale, Loricariichthys anus (Siluriformes) e Pachyurus bonariensis (Perciformes) no Lago Guaíba e Laguna dos Patos, RS. Biociências 15(2):230-256.

Mega, D. F. F. \& Bemvenuti, M. A. 2006. Guia didático sobre alguns peixes da Lagoa Mangueira, RS. Cadernos de Ecologia Aquática 1(2):1-15.

R Core Team. 2015. R: A Language and Environment for Statistical Computing. Available at: <http://www.R-project.org/>. Accessed on: 26 May 2016.

Sмітн, R. J. 1980. Rethinking allometry. Journal of Theoretical Biology 87(1):97-111.

ZAR, J. H. 1999. Biostatistical Analysis. New Jersey, Prentice-Hall. 663p. 